\title{
Soil Microbial Population and Soil Enzymatic Activity in Finger Millet as Influenced by Effect of Planting Geometry, Methods of Establishment and Nutrient Sources
}

\author{
Narayan Hebbal*, B.K. Ramachandrappa, M.N. Thimmegouda, \\ Mudalagiriyappa and G.P. Brahmaprakash
}

\author{
Department of Agronomy, College of Agriculture, UAS, GKVK, Bangalore - 560065 \\ *Corresponding author
}

\section{A B S T R A C T}

\section{Keywords}

Soil microbial population, Soil enzymatic activity, Finger millet

Article Info

Accepted:

16 February 2018

Available Online:

10 March 2018
Field experiment was conducted during Kharif-2015 at AICRP on dryland agriculture project, Gandhi Krishi Vignana Kendra (GKVK), UAS, Bangalore to assess the effect of planting geometry, method of establishment and nutrient source on soil microbial population and soil enzymatic activity in finger millet. Application of FYM on $\mathrm{N}$ equivalent basis + FYM at $7.5 \mathrm{t} \mathrm{ha}^{-1}$ recorded significantly higher population of bacteria, fungi, actinomycetes (31.58, 16.11 and 10.03, respectively) and higher activity of urease, dehydrogenase, acid phosphatase and alkaline phosphatase activity $\left(22.49 \mu \mathrm{g} \mathrm{NH}_{4}-\mathrm{N}_{\mathrm{g}}\right.$ soil $^{-1} \mathrm{hr}^{-1}, 109.01 \mu \mathrm{g}$ TPF $\mathrm{g}$ soil $^{-1} 24 \mathrm{hr}^{-1}, 28.87 \mathrm{~g}$ PNP g soil ${ }^{-1}$ and $22.76 \mathrm{~g}$ PNP g soil ${ }^{-1}$ urease, respectively) compared to application of recommended dose of FYM at $7.5 \mathrm{t} \mathrm{ha}^{-1}+$ RDF 50:40:37.5 kg N P K ha ${ }^{-1}(30.39,14.91$ and 9.00 respectively for bacteria, fungi and actinomycetes) and $21.59 \mu \mathrm{g} \mathrm{NH}_{4}-\mathrm{N} \mathrm{g} \mathrm{soil}^{-1} \mathrm{hr}^{-1}, 102.98 \mu \mathrm{g}$ TPF g soil ${ }^{-1} 24 \mathrm{hr}^{-1}, 25.56 \mathrm{~g}$ PNP g soil ${ }^{-1}$ and $19.80 \mathrm{~g}$ PNP $\mathrm{g} \mathrm{soil}^{-1}$, respectively for urease, dehydrogenase, acid and alkaline phosphatase activity of soil. Whereas the other factors like methods of establishment and planting geometry found to be non-significant.

\section{Introduction}

In the recent years, there has been reduction in the usage of organic manures and increase in the use of inorganic fertilizers to obtain higher yields from hybrids and improved varieties. The conjunctive use of chemical fertilizers and organic manures is important to maintain and sustain soil fertility and crop productivity. Organic manures enrich soil organic matter, improve soil physical and biological environment and act as store house of nutrients. The enzyme activity in soil is considered as an index of microbial activity, which is influenced by nature, age of crop and addition of fertilizers and manures. Intensive use of fertilizers, nutrients, manures and other soil amendments used to maximize production may thus affect soil properties. The activities of micro-organisms play a major role in nutrient recycling, organic matter decomposition and turnover. The population and functions of microorganisms cannot be over-looked while considering the 
soil health because microorganisms provide living environment to the soil and perform various functions like transformation of nutrients to available forms, decomposition of organic residues, biochemical activities and enzymatic activities. Soil enzyme activities are 'sensors' of soil degradation since they integrate information about microbial status and physico-chemical conditions of soil in relation to nutrients availability (Aon and Colaneri, 2001).

Organic wastes are the testimony of valuable role of organic matter in maintaining a good health of the soil in terms of improving physiochemical properties, microbial population and their activities; and increasing nutrient availability to the crop plants. Farm yard manure besides being a good source of carbon and nutrients is also responsible for increasing the organic matter status of the soil. Hence, a field experiment was conducted to know the effect of planting geometry, method of establishment and nutrient source on soil microbial population and soil enzymatic activity in finger millet.

\section{Materials and Methods}

\section{Enumeration of soil microbial populations}

Soil microbial populations were enumerated from soil samples collected after harvest of crop at $0-15 \mathrm{~cm}$ depth. The rhizosphere soil samples collected from experimental soil were analyzed for different soil microorganisms viz., total bacteria, fungi and actinomycetes using standard dilution plate count technique and plating on specific nutrient media. The soil samples collected were mixed thoroughly and were subjected to serial dilution using $1 \mathrm{~g}$ of soil in $100 \mathrm{ml}$ of distilled water. The enumeration of microorganisms was done after culturing these organisms using different media by standard dilution plate technique. The media used were soil extract agar for bacteria, Martins Rose Bengal agar with streptomycin sulphate for fungi and Kuster's agar for actinomycetes. The number of colonies were counted and multiplied by the dilution factor for the concerned group of microorganisms and expressed as number of colony forming units (CFU) per gram of oven dry soil.

\section{Soil dehydrogenase activity}

The pre incubated soil sample $(2 \mathrm{~g})$ received 1 $\mathrm{ml}$ of 2, 3, 5- triphenyl tetrazolium chloride (3 $\%)$ and $2.5 \mathrm{ml}$ of distilled water to create anaerobic conditions. Samples were mixed thoroughly with glass rod and incubated at 37 ${ }^{\circ} \mathrm{C}$ for 24 hours. The soil solution was filtered through cotton plug at the tip of the funnel and washed with methanol and diluted to 100 $\mathrm{ml}$. The red color intensity was measured at 485 ๆm (Casida et al., 1964) by taking methanol as blank.

\section{Soil urease activity}

Determination of urease enzyme was carried out by adopting the methodology as given by Tabatabai (1982). In this method, the unhydrolysed urea was complexed with a coloring agent and the color intensity is directly proportional to the urease present. The pre incubated soil sample $(1 \mathrm{~g})$ in $50 \mathrm{ml}$ Erlenmeyer flask was treated with $0.2 \mathrm{ml}$ toluene and $1 \mathrm{ml}$ of $0.2 \mathrm{M}$ urea solution and thoroughly mixed by swirling for few seconds and incubated at $37{ }^{\circ} \mathrm{C}$ for 2 hours. After incubation, $35 \mathrm{ml}$ of $\mathrm{KCl}-\mathrm{AgSO}_{4}$ was added and swirled again, allowed to stand still and the contents were cooled at room temperature. The volume was then made up to $50 \mathrm{ml}$ with addition of $\mathrm{KCl}-\mathrm{AgSO}_{4}$. A known quantity of this filtrate was used for measuring the unhydrolysed urea by colorimetric method. Nessler's reagent was used to develop the color and the intensity was measured at 510 $\eta \mathrm{m}$ using UV spectrophotometer. 


\section{Results and Discussion}

In the recent years, there has been reduction in the usage of organic manures and increase in the use of inorganic fertilizers to realise higher yields from hybrids and improved varieties. The conjunctive use of chemical fertilizers and organic manures is important to maintain and sustain soil fertility and crop productivity. Organic manures enrich soil organic matter, improve soil physical and biological environment and act as store house of nutrients. The enzyme activity in soil is considered as an index of microbial activity, which is influenced by nature, age of crop and addition of fertilizers and manures.

Intensive use of fertilizers, nutrients, manures and other soil amendments used to maximize production may thus affect soil properties. The activities of micro-organisms play a major role in nutrient recycling, organic matter decomposition and turnover. The population and functions of microorganisms cannot be over-looked while considering the soil health because, microorganisms provide living environment to the soil and perform various functions like transformation of nutrients to available forms, decomposition of organic residues, biochemical activities and enzymatic activities. Soil enzyme activities are 'sensors' of soil degradation since they integrate information about microbial status and physico-chemical conditions of soil in relation to nutrients availability (Aon and Colaneri, 2001).

Soil quality highly depends on its structure, natural productivity and human influence. As a consequence, microbiological properties such as soil enzyme activities have been suggested as potential indicators of soil quality because of their rapid response to changes in soil management.

Different planting geometry, methods of establishment and nutrient source have influenced the population of bacteria, fungi, actinomycetes, urease, dehydrogenase, acid phosphatase and alkaline phosphatase activity. Non-significant result was observed with different methods of establishment. Transplanting of finger millet has recorded numerically higher population of bacteria, fungi, actinomycetes $(31.22,15.67$, and 9.75, respectively) and enzyme activity $(22.27 \mu \mathrm{g}$ $\mathrm{NH}_{4}-\mathrm{N}$ g soil ${ }^{-1} \mathrm{hr}^{-1}$ urease, $106.67 \mu \mathrm{g}$ TPF $\mathrm{g}$ soil $^{-1} 24 \mathrm{hr}^{-1}$ dehydrogenase, $27.26 \mathrm{~g}$ PNP g soil $^{-1}$ acid phosphatase and $21.39 \mathrm{~g}$ PNP $\mathrm{g}$ soil $^{-1}$ alkaline phosphatase activity) of soil. Whereas, lesser population of microorganisms (30.75, 15.36 and 9.28, bacteria, fungi, actinomycetes, respectively) and enzyme activity $\left(21.81 \mu \mathrm{g} \mathrm{NH} 4-\mathrm{N} \mathrm{g} \mathrm{soil}{ }^{-1} \mathrm{hr}^{-1}\right.$ urease, $105.32 \mu \mathrm{g}$ TPF g soil ${ }^{-1} 24 \mathrm{hr}^{-1}$ dehydrogenase, $27.17 \mathrm{~g}$ PNP g soil ${ }^{-1}$ acid phosphatase and $21.17 \mathrm{~g}$ PNP g soil ${ }^{-1}$ alkaline phosphatase activity) were observed in direct sowing.

With respect to planting geometry, nonsignificant results were noticed in microbial population and enzyme activity of soil.

However, numerically higher population of bacteria (31.33), fungi (15.75) and actinomycetes $(9.75)$ was observed with $45 \times$ $30 \mathrm{~cm}$ spacing followed by $30 \times 30 \mathrm{~cm}$ (30.83, 15.50 and 9.42, respectively) and $30 \times$ $10 \mathrm{~cm}$ (30.79, 14.75 and 9.38, respectively) spacing. However, numerically higher urease activity was found with $45 \times 30 \mathrm{~cm}$ spacing

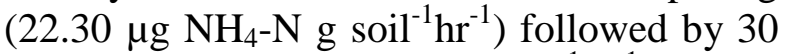
$\times 10 \mathrm{~cm}\left(21.92 \mu \mathrm{g} \mathrm{NH}_{4}-\mathrm{N} \mathrm{g} \mathrm{soil}{ }^{-1} \mathrm{hr}^{-1}\right)$ and 30 $\times 30 \mathrm{~cm}$ spacing $\left(21.89 \mu \mathrm{g} \mathrm{NH} 4-\mathrm{N}\right.$ g soil ${ }^{-1}$ $\mathrm{hr}^{-1}$ ). Higher dehydrogenase activity was recorded with $30 \times 30 \mathrm{~cm}$ spacing $(107.34 \mu \mathrm{g}$ TPF g soil ${ }^{-1} 24 \mathrm{hr}^{-1}$ ) followed by $45 \times 30 \mathrm{~cm}$ spacing (105.44 $\mu \mathrm{g}$ TPF g soil $\left.{ }^{-1} 24 \mathrm{hr}^{-1}\right)$ and $30 \times 10 \mathrm{~cm}$ spacing $\left(105.20 \mu \mathrm{g}\right.$ TPF $\mathrm{g} \mathrm{soil}^{-1}$ $\left.24 \mathrm{hr}^{-1}\right)$. Higher acid phosphatase activity was found with $30 \times 30 \mathrm{~cm}$ spacing $(27.26 \mathrm{~g}$ PNP $\left.\mathrm{g} \mathrm{soil}^{-1}\right)$ followed by $45 \times 30 \mathrm{~cm}$ spacing $(27.23$ g PNP g soil $\left.^{-1}\right)$ and $30 \times 10 \mathrm{~cm}$ spacing $(27.14$ g PNP g soil ${ }^{-1}$ ). 
Table.1 Soil microbial population as influenced by planting geometry, methods of establishment and nutrient sources in finger millet

\begin{tabular}{|c|c|c|c|c|c|c|c|c|c|}
\hline \multirow[t]{2}{*}{ Treatments } & \multicolumn{3}{|c|}{ Bacteria $\left(10^{5} \mathrm{CFU}\right)$} & \multicolumn{3}{|c|}{ Fungi $\left(10^{4} \mathrm{CFU}\right)$} & \multicolumn{3}{|c|}{$\begin{array}{l}\text { Actinomycetes } \\
\left(10^{3} \mathrm{CFU}\right)\end{array}$} \\
\hline & 2015 & 2016 & Pooled & 2015 & 2016 & Pooled & 2015 & 2016 & Pooled \\
\hline \multicolumn{10}{|l|}{ Methods of establishment } \\
\hline$M_{1}=$ Direct sowing (spot placement) & 31.72 & 29.78 & 30.75 & 15.89 & 14.83 & 15.36 & 9.83 & 8.72 & 9.28 \\
\hline$M_{2}=$ Transplanting & 32.22 & 30.22 & 31.22 & 16.17 & 15.17 & 15.67 & 10.17 & 9.33 & 9.75 \\
\hline S. Em. \pm & 0.31 & 0.30 & 0.21 & 0.22 & 0.23 & 0.16 & 0.23 & 0.26 & 0.17 \\
\hline C.D.@ 5\% & NS & NS & NS & NS & NS & NS & NS & NS & NS \\
\hline \multicolumn{10}{|l|}{ Planting geometry } \\
\hline $\begin{aligned} & S_{1}= \text { Recommended spacing } 30 \mathrm{~cm} \times \\
& 10 \mathrm{~cm}\end{aligned}$ & 31.75 & 29.83 & 30.79 & 15.83 & 14.75 & 15.29 & 9.92 & 8.83 & 9.38 \\
\hline$S_{2}=30 \mathrm{~cm} \times 30 \mathrm{~cm}$ & 31.83 & 29.83 & 30.83 & 16.00 & 15.00 & 15.50 & 9.83 & 9.00 & 9.42 \\
\hline$S_{3}=45 \mathrm{~cm} \times 30 \mathrm{~cm}$ & 32.33 & 30.33 & 31.33 & 16.25 & 15.25 & 15.75 & 10.25 & 9.25 & 9.75 \\
\hline S. Em. \pm & 0.38 & 0.37 & 0.26 & 0.27 & 0.29 & 0.19 & 0.28 & 0.32 & 0.21 \\
\hline C.D.@5\% & NS & NS & NS & NS & NS & NS & NS & NS & NS \\
\hline \multicolumn{10}{|l|}{ Nutrient source } \\
\hline $\begin{array}{c}\mathrm{N}_{1}=\text { Recommended dose (FYM at } 7.5 \\
\mathrm{t} \mathrm{ha}^{-1}+\mathrm{RDF} 50: 40: 37.5 \mathrm{~kg} \mathrm{NPK} \\
\left.\mathrm{ha}^{-1}\right)\end{array}$ & 31.39 & 29.39 & 30.39 & 15.44 & 14.39 & 14.91 & 9.50 & 8.50 & 9.00 \\
\hline $\begin{array}{l}\mathrm{N}_{2}=\text { FYM at } 7.5 \mathrm{t} \mathrm{ha}^{-1}+\mathrm{FYM} \text { on } \mathrm{N} \\
\text { equivalent basis }\end{array}$ & 32.56 & 30.61 & 31.58 & 16.61 & 15.61 & 16.11 & 10.50 & 9.56 & 10.03 \\
\hline S. Em. \pm & 0.31 & 0.30 & 0.21 & 0.22 & 0.23 & 0.15 & 0.23 & 0.26 & 0.17 \\
\hline C.D.@5\% & 0.91 & 0.89 & 0.60 & 0.66 & 0.68 & 0.450 & 0.67 & 0.76 & 0.48 \\
\hline \multicolumn{10}{|c|}{ Methods of establishment $\times$ Planting geometry $(M \times S)$} \\
\hline S. Em. \pm & 0.54 & 0.53 & 0.37 & 0.39 & 0.40 & 0.27 & 0.40 & 0.45 & 0.29 \\
\hline C.D.@5\% & NS & NS & NS & NS & NS & NS & NS & NS & NS \\
\hline \multicolumn{10}{|c|}{ Methods of establishment $\times$ nutrient source $(M \times N)$} \\
\hline S. Em. \pm & 0.44 & 0.43 & 0.30 & 0.32 & 0.33 & 0.22 & 0.32 & 0.37 & 0.24 \\
\hline C.D.@5\% & NS & NS & NS & NS & NS & NS & NS & NS & NS \\
\hline \multicolumn{10}{|c|}{ Planting geometry $\times$ nutrient source $(S \times N)$} \\
\hline S. Em. \pm & 0.54 & 0.53 & 0.37 & 0.39 & 0.40 & 0.27 & 0.40 & 0.45 & 0.29 \\
\hline C.D.@ 5\% & NS & NS & NS & NS & NS & NS & NS & NS & NS \\
\hline \multicolumn{10}{|c|}{ Methods of establishment $\times$ Planting geometry $x$ Nutrient source $(M \times S \times N)$} \\
\hline S. Em. \pm & 0.76 & 0.75 & 0.52 & 0.55 & 0.57 & 0.39 & 0.56 & 0.63 & 0.42 \\
\hline C.D.@5\% & NS & NS & NS & NS & NS & NS & NS & NS & NS \\
\hline
\end{tabular}

Note: CD-Critical difference, NS-Non significant 
Table.2 Soil enzymatic activity as influenced by planting geometry, methods of establishment and nutrient sources in finger millet

\begin{tabular}{|c|c|c|c|c|c|c|c|c|c|c|c|c|}
\hline \multirow[t]{2}{*}{ Treatments } & \multicolumn{3}{|c|}{$\begin{array}{c}\text { Urease } \\
\left(\mu \mathrm{g} \mathrm{NH} 4-\mathrm{N} \text { g soil }^{-1} \mathrm{hr}^{-1}\right)\end{array}$} & \multicolumn{3}{|c|}{$\begin{array}{c}\text { Dehydrogenase } \\
\left(\mu \mathrm{g} \text { TPF } \text { g soil }^{-1} 24 \mathrm{hr}^{-1}\right)\end{array}$} & \multicolumn{3}{|c|}{$\begin{array}{l}\text { Acid phosphatase } \\
\quad\left(\mathrm{g} \mathrm{PNP} \mathrm{g}^{-1}\right)\end{array}$} & \multicolumn{3}{|c|}{$\begin{array}{l}\text { Alkaline phosphatase } \\
\left.\text { (g PNP } \text { g }^{-1}\right)\end{array}$} \\
\hline & 2015 & 2016 & Pooled & 2015 & 2016 & Pooled & 2015 & 2016 & Pooled & 2015 & 2016 & Pooled \\
\hline \multicolumn{13}{|l|}{ Methods of establishment } \\
\hline$M_{1}=$ Direct sowing (spot placement) & 22.30 & 21.32 & 21.81 & 108.88 & 101.77 & 105.32 & 28.17 & 26.17 & 27.17 & 21.91 & 20.43 & 21.17 \\
\hline $\mathbf{M}_{2}=$ Transplanting & 22.87 & 21.66 & 22.27 & 110.70 & 102.64 & 106.67 & 28.26 & 26.26 & 27.26 & 22.22 & 20.56 & 21.39 \\
\hline S. Em. \pm & 0.25 & 0.24 & 0.17 & 1.24 & 1.25 & 0.86 & 0.22 & 0.22 & 0.15 & 0.16 & 0.16 & 0.11 \\
\hline C.D.@ 5\% & NS & NS & NS & NS & NS & NS & NS & NS & NS & NS & NS & NS \\
\hline \multicolumn{13}{|l|}{ Planting geometry } \\
\hline$S_{1}=$ Recommended spacing $30 \mathrm{~cm} \times 10 \mathrm{~cm}$ & 22.44 & 21.41 & 21.92 & 108.95 & 101.45 & 105.20 & 28.14 & 26.14 & 27.14 & 21.95 & 20.51 & 21.23 \\
\hline$S_{2}=30 \mathrm{~cm} \times 30 \mathrm{~cm}$ & 22.46 & 21.33 & 21.89 & 111.35 & 103.35 & 107.34 & 28.26 & 26.26 & 27.26 & 22.37 & 20.60 & 21.48 \\
\hline$S_{3}=45 \mathrm{~cm} \times 30 \mathrm{~cm}$ & 22.86 & 21.75 & 22.30 & 109.07 & 101.82 & 105.44 & 28.23 & 26.23 & 27.23 & 21.87 & 20.37 & 21.12 \\
\hline S. Em. \pm & 0.30 & 0.29 & 0.20 & 1.52 & 1.52 & 1.05 & 0.26 & 0.27 & 0.19 & 0.19 & 0.19 & 0.13 \\
\hline C.D.@ 5\% & NS & NS & NS & NS & NS & NS & NS & NS & NS & NS & NS & NS \\
\hline \multicolumn{13}{|l|}{ Nutrient source } \\
\hline $\begin{aligned} \mathrm{N}_{1}= & \text { Recommended dose }\left(\mathrm{FYM} \text { at } 7.5 \mathrm{t} \mathrm{ha}^{-1}+\right. \\
& \text { RDF } \\
& \left.50: 40: 37.5 \mathrm{~kg} \mathrm{NPK} \mathrm{ha}^{-1}\right)\end{aligned}$ & 22.08 & 21.10 & 21.59 & 106.56 & 99.40 & 102.98 & 26.56 & 24.56 & 25.56 & 20.51 & 19.09 & 19.80 \\
\hline $\begin{array}{l}\mathrm{N}_{2}=\mathrm{FYM} \text { at } 7.5 \mathrm{t} \mathrm{ha}^{-1}+\mathrm{FYM} \text { on } \mathrm{N} \text { equivalent } \\
\text { basis }\end{array}$ & 23.10 & 21.88 & 22.49 & 113.01 & 105.01 & 109.01 & 29.87 & 27.87 & 28.87 & 23.61 & 21.90 & 22.76 \\
\hline S. Em. \pm & 0.25 & 0.24 & 0.17 & 1.24 & 1.25 & 0.862 & 0.22 & 0.22 & 0.15 & 0.16 & 0.16 & 0.11 \\
\hline C.D.@ 5\% & 0.72 & 0.69 & 0.48 & 3.65 & 3.65 & 2.454 & 0.64 & 0.64 & 0.43 & 0.47 & 0.46 & 0.31 \\
\hline \multicolumn{13}{|c|}{ Methods of establishment $\times$ Planting geometry $(M \times S)$} \\
\hline S. Em. \pm & 0.42 & 0.41 & 0.29 & 2.16 & 2.16 & 1.49 & 0.38 & 0.38 & 0.26 & 0.28 & 0.27 & 0.19 \\
\hline C.D.@5\% & NS & NS & NS & NS & NS & NS & NS & NS & NS & NS & NS & NS \\
\hline \multicolumn{13}{|l|}{ Methods of establishment $\times$ nutrient source $(M \times N)$} \\
\hline S. Em. \pm & 0.35 & 0.34 & 0.24 & 1.76 & 1.76 & 1.22 & 0.31 & 0.31 & 0.21 & 0.23 & 0.22 & 0.15 \\
\hline C.D.@ 5\% & NS & NS & NS & NS & NS & NS & NS & NS & NS & NS & NS & NS \\
\hline \multicolumn{13}{|l|}{ Planting geometry $\times$ nutrient source $(S \times N)$} \\
\hline S. Em. \pm & 0.42 & 0.41 & 0.29 & 2.16 & 2.16 & 1.49 & 0.38 & 0.38 & 0.26 & 0.28 & 0.27 & 0.19 \\
\hline C.D.@ 5\% & NS & NS & NS & NS & NS & NS & NS & NS & NS & NS & NS & NS \\
\hline \multicolumn{13}{|c|}{ Methods of establishment $\times$ Planting geometry $\times$ Nutrient source $(M \times S \times N)$} \\
\hline S. Em. \pm & 0.60 & 0.58 & 0.41 & 3.05 & 3.05 & 2.11 & 0.54 & 0.54 & 0.37 & 0.39 & 0.38 & 0.27 \\
\hline C.D.@ 5\% & NS & NS & NS & NS & NS & NS & NS & NS & NS & NS & NS & $\mathrm{NS}$ \\
\hline
\end{tabular}

Note: CD-Critical difference, NS-Non significant 
Alkaline phosphatase activity was found higher with $30 \times 30 \mathrm{~cm}$ spacing $(21.48 \mathrm{~g}$ PNP $\mathrm{g} \mathrm{soil}{ }^{-1}$ ) followed by $30 \times 10 \mathrm{~cm}$ spacing $\left(21.23 \mathrm{~g} \mathrm{PNP} \mathrm{g} \mathrm{soil}^{-1}\right)$ and $45 \times 30 \mathrm{~cm}$ spacing (21.12 g PNP g soil ${ }^{-1}$ ).

Application of FYM on $\mathrm{N}$ equivalent basis + FYM at $7.5 \mathrm{t} \mathrm{ha}^{-1}$ recorded significantly higher population of bacteria, fungi, actinomycetes (31.58, 16.11 and 10.03, respectively) and higher activity of urease, dehydrogenase, acid phosphatase and alkaline phosphatase activity $\left(22.49 \mu \mathrm{g} \mathrm{NH}_{4}-\mathrm{N} \mathrm{g} \mathrm{soil}{ }^{-1}\right.$ $\mathrm{hr}^{-1}, 109.01 \mu \mathrm{g}$ TPF g soil ${ }^{-1} 24 \mathrm{hr}^{-1}, 28.87 \mathrm{~g}$ PNP g soil ${ }^{-1}$ and $22.76 \mathrm{~g}$ PNP $\mathrm{g}$ soil $^{-1}$ urease, respectively) compared to application of recommended dose of FYM at $7.5 \mathrm{t} \mathrm{ha}^{-1}+$ RDF 50:40:37.5 kg N P K ha ${ }^{-1}$ (30.39, 14.91 and 9.00 respectively for bacteria, fungi and actinomycetes) and $21.59 \mu \mathrm{g} \mathrm{NH}-\mathrm{N}$ g soil ${ }^{-1}$ $\mathrm{hr}^{-1}, 102.98 \mu \mathrm{g}$ TPF g soil ${ }^{-1} 24 \mathrm{hr}^{-1}, 25.56 \mathrm{~g}$ PNP g soil ${ }^{-1}$ and 19.80 g PNP g soil ${ }^{-1}$, respectively for urease, dehydrogenase, acid and alkaline phosphatase activity of soil. Higher enzyme activities like dehydrogenase and urease were seen in FYM treated plots than the control. Similarly Sharma et al., (2003) and Singaram and Kamalakumari (2005) also reported the maximum enzyme activity (Amylase, catalase, cellulose, dehydrogenase, phosphatase and urease) with FYM application.

Organic wastes are the testimony of valuable role of organic matter in maintaining a good health of the soil in terms of improving physicochemical properties, microbial population and their activities; and increasing nutrient availability to the crop plants. Farm yard manure besides being a good source of carbon and nutrients is also responsible for increasing the organic matter status of the soil.

The activity of enzymes can be attributed to microbial origin developed during decomposition of organic sources of nutrients. Addition of organic manures acts as good source of carbon and energy to heterotrophs by which their population increased with an increase in enzymatic activities. Measurement of dehydrogenase represents immediate metabolic activities of soil microorganism at the time of the test. Soil dehydrogenase activity is an oxidative degradation process i.e., dehydrogenation of organic matter by transferring hydrogen and electrons from substrate to acceptors. Dehydrogenase enzymes play a significant role in the biological oxidation of soil organic matter and thus serve as an indicator of the microbiological redox systems and may be considered a good measure of microbial oxidative activities in soils.

Enzymes play a key role in biochemical process of organic matter decomposition in the soil (Sinsabaugh et al., 1991). They are important in catalysing several vital reactions necessary for the life processes of microorganisms in soils and the stabilization of soil structure, the decomposition of organic wastes, organic matter formation and nutrient cycling, hence playing an important role in agriculture. The enzyme levels in soil systems vary in amounts primarily due to the fact that each soil type has different amounts of organic matter content, composition and activity of its living organisms and intensity of biological processes.

In practice, biochemical reactions are brought about largely through the catalytic contribution of enzymes and variable substrates that serve as energy sources for microorganisms. Shukla and Varma (2011), Geeta Singh et al., (2015) support these findings and quoted that application of FYM has increased the activity of microbes and enzymes as compared to control (Table 1 and $2)$. 
None of the interaction effects were found to be significant with respect to soil biological properties.

\section{References}

Casida, L. E., Klein, D. A. and Santro, 1964, Soil dehydrogenase activity Soil Biol. Biochem., 22(7): 190-193.

Tabatabai, M. A., 1982, Soil enzymes. In: Methods of soil analysis, Part 2 (Eds). A.L. Page, R.H. Miller and D.R. Keeney, American Society of Agronomy, Soil science Society of America, Madison, Wisconsin, USA. pp. 903-947.

Aon, M. A. and Colaneri, A. C., 2001, Temporal and spatial evaluation of enzymatic activities and physicochemical properties in an agricultural soil.App. Soil Eco., 18: 255-270.

Sharma, D. P., Sharma, T. R., Agrawal, S. B. and Rawat, A., 2003, Differential response of wheat to organic and inorganic fertilizers.JNKVV Res. J., 37(2): 17-19.

Singaram, P. and Kamalakumari, K., 2005, Long-term effect of FYM and fertilizers on enzyme dynamics of soil. J. Indian Soc. Soil Sci., 43(3): 378381.

Sinsabaugh, R. L., Antibus, R. K. and Linkins, A. E., 1991, Anenzymic approach to the analysis of microbial activity during plant litter decomposition. Agri. Ecosyst. Environ., 34: 43-54.

Shukla, G. and Varma, A., 2011, Soil enzymes, Springer Publications, XVI, p. 384.

Geeta Singh, Kumar, D. and Sharma, P., 2015, Effect of organics, biofertilizers and crop residue application on soil microbial activity in rice-wheat and rice-wheat mungbean cropping systems in the Indo-Gangetic plains. Cogent Geosci., 1:1-14.

\section{How to cite this article:}

Narayan Hebbal, B.K. Ramachandrappa, M.N. Thimmegouda, Mudalagiriyappa and Brahmaprakash, G.P. 2018. Soil Microbial Population and Soil Enzymatic Activity in Finger Millet as Influenced by Effect of Planting Geometry, Methods of Establishment and Nutrient Sources. Int.J.Curr.Microbiol.App.Sci. 7(03): 2096-2102.

doi: https://doi.org/10.20546/ijcmas.2018.703.246 